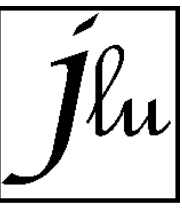

https://jurnal.univpgri-

palembang.ac.id/index.php/luminous
Jurnal Luminous:

Riset Ilmiah Pendidikan Fisika

Vol. 1 No. 2 (2020) hal 39-45
E-ISSN 2715-6990

P-ISSN 2715-9582

Juli 2020

\title{
PENERAPAN MODEL PEMBELAJARAN NUMBERED HEAD TOGETHER (NHT) DENGAN PENDEKATAN PROJEK UNTUK MENINGKATKAN KEMAMPUAN KOGNITIF SISWA
}

\author{
Agi Dahtiar \\ Program Studi Agribisnis, Fakultas Pertanian, Universitas Winaya Mukti \\ Jln. Tanjungsari-Sumedang km 29 Sumedang, Jawa Barat \\ agidahtiar@unwim.ac.id
}

Received: 28 April 2020. Accepted: 25 Juni 2020. Published: Juli 2020

\begin{abstract}
Abstrak
Hasil studi pendahuluan di salah satu SMA Negeri di Bandung menunjukkan bahwa pembelajaran fisika masih bersifat informatif. Hal ini mengakibatkan hasil belajar siswa rendah. Proses pembelajaran model NHT dengan pendekatan projek memberikan kesempatan pada siswa untuk saling membagikan ide-ide dan mempertimbangkan jawaban yang paling tepat dalam suatu permasalahan. Penelitian ini bertujuan untuk meningkatkan kemampuan kognitif siswa SMA. Metode penlitian yang digunakan adalah jenis pre-experiment dengan desain penelitian one group pretest-posttest design. Sampel penelitian yaitu kelas $\mathrm{X}-1$. Pengumpulan data dilakukan dengan menggunakan tes berupa pilihan ganda. Dari hasil penelitian menunjukan rata-rata gain ternormalisasi $<\mathrm{g}>$ antara pretes dan postes, menghasilkan gain $<\mathrm{g}>$ sebesar 0,41 , hal ini menunjukkan bahwa peningkatan kemampuan kognitif siswa pada kategori sedang. Sehingga dapat disimpulkan bahwa model numbered head together (NHT) dengan pendekatan projek dapat meningkatkan kemampuan kognitif siswa
\end{abstract}

(c) 20XX Pendidikan Fisika FKIP UPGRI Palembang

Kata Kunci: Kemampuan Kognitif, Model NHT, Pendekatan Projek

\section{PENDAHULUAN}

Berdasarkan hasil studi pendahuluan melalui penyebaran kuisoner kepada seluruh siswa pada kelas X-1 di salah satu SMA Negeri Kabupaten Bandung dalam mata pelajaran Fisika. Dari beberapa pertanyaan yang dijawab oleh kebanyakan siswa, menunjukan bahwa proses pembelajaran masih bersifat informatif, sedangkan praktikum dilaksanakan hanya satu kali pada pokok bahasan Gerak Melingkar Berubah Beraturan (GLBB). Karena proses pembelajaran masih bersifat informatif dan kurang terlaksananya kegiatan praktikum, sehingga berdampak pada hasil belajar siswa. Hal ini terbukti dengan ratarata hasil belajar siswa yang rendah pada materi suhu dan kalor yaitu sebesar 57 dengan skala maksimum 100. Studi pendahuluan dilakukan melalui paper dan person. Paper yang dipergunakan dalam penelitian adalah hasil 
ulangan sebelum remedial, sedangkan person penyebaran kuisoner kepada siswa.

Untuk mengatasi permasalahan di atas, perlu diadakan suatu inovasi pada proses pembelajaran. Inovasi proses pembelajaran tersebut haruslah memberikan sarana bagi siswa untuk lebih beraktifitas dan berperan aktif secara langsung ketika proses pembelajaran sehingga diharapkan dapat memicu semangat siswa dalam mengikuti proses pembelajaran dan memicu semangat siswa dalam berprestasi. Inovasi pembelajaran tersebut adalah model pembelajaran kooperatif tipe numbered head together (NHT) dengan pendekatan projek.

Proses pembelajaran NHT memberikan kesempatan pada siswa untuk saling membagikan ide-ide dan mempertimbangkan jawaban yang paling tepat serta mendorong siswa untuk meningkatkan semangat kerjasama (Lie, 2002 : 58). Dapat disimpulkan bahwa melalui model pembelajaran NHT, siswa dapat bekerjasama dan mempunyai pengetahuan secara merata, sehingga diharapkan mampu meningkatkan kemampuan kognitif siswa.

Sedangkan melalui pendekatan projek yang terdiri dari tahap merencanakan, membuat, dan mempresentasikan sebuah proyek membuat alat sederhana diharapkan siswa mampu memperkuat dan memperkaya pengetahuan dasar yang dimilikinya. Konsep-konsep dasar yang dimiliki oleh siswa diharapkan dapat diperkaya ketika proses merencanakan, dimana mereka dituntut untuk menentukan alat dan bahan, gambar desain, serta prosedur kerja alat yang akan mereka buat. Ketika proses pembuatan alat, konsep-konsep yang dimiliki siswa diharapkan dapat diperkuat dengan membuat alat sampai alat tersebut berkerja dengan baik. Proses yang terakhir adalah persentasi, proses ini adalah salah satu bentuk pertanggungjawaban dari apa yang mereka buat, sehingga konsep-konsep yang mereka bangun bukan hanya dimengerti sesaat dan sebagian saja, tetapi harus menyeluruh karena masing-masing kelompok siswa harus menjelaskan semuanya didepan teman-teman mereka. Jadi dapat disimpulkan bahwa projek diharapkan dapat meningkatkan kemampuan kognitif siswa.

Hasil penelitian yang dilakukan oleh Sema Altun Yalcin (2009) dalam jurnalnya yang berjudul "The Effect of project on Science Undergraduates' Learning of Electricity, Attitude towards Physics and Scientific Process Skills" menunjukan bahwa projek dapat meningkatkan kemampuan kognitif siswa. Dia menggunakan projek sebagai salah satu pendekatan dalam materi pembelajaran kelistrikan. Selain itu penelitian Shacha micthell (2009) dengan jurnalnya yang berjudul "The Negotiated Project Approach: project without Leaving the Standards Behind" menunjukan bahwa pendekatan project dapat membantu anak menemukan tujuan pembelajaran mereka, membentuk konsep yang baik yang ada dalam dirinya dan memotivasi mereka untuk menyelidiki sebuah permasalahan.

Penelitian dilakukan mengacu pada penelitian projek yang dilakukan oleh Sema Altun Yalcin. Penelitian dilakukan pada sub materi alatalat optik sekolah menengah atas. Perbedaan dari penelitian yang dilakukan oleh Sema Altun dalam jurnalnya "The Effect of project on Science Undergraduates' Learning of Electricity, Attitude towards Physics and Scientific Process Skills"; penelitian ini dilakukan di tempat, objek maupun subjek yang berbeda.

Penelitian ini penting dilakukan untuk menghasilkan peningkatan kemampuan kognitif siswa. Selain itu, kemampuan-kemampuan yang didapat oleh siswa yaitu pemahaman konsep yang akan lebih melekat pada dirinya, karena pemahaman konsep yang mereka miliki diterapkan dalam proses pembuatan alat. Oleh karena itu penulis bermaksud untuk melakukan penelitian mengenai peningkatan kemampuan kognitif siswa dengan menggunakan model NHT dengan pendekatan projek, dengan judul penelitian: "Penerapan Model Pembelajaran Numbered Head Together (NHT) dengan Pendekatan Projek untuk Meningkatkan Kemampuan Kognitif Siswa SMA pada Pembelajaran Fisika".

Model Numbered Head Together (Sriayu, 2009) adalah suatu model pembelajaran yang 
lebih mengedepankan kepada aktivitas siswa dalam mencari, mengolah, dan melaporkan informasi dari berbagai sumber yang akhirnya dipresentasikan di depan kelas. Adapun langkahlangkah pembelajaran Numbered Head Together: yaitu Penomoran, mengajukan pertanyaan, berikpikir bersama, Menjawab.

Pendekatan project based learning menurut Solamo (2002) adalah pembelajaran yang sistematik dimana siswa diikut sertakan dalam proses pembelajaran untuk mengembangkan pengetahuan dasar dan keterampilan yang berkesinambungan. Siswa juga terlibat dalam proses inquiry tersetruktur untuk menghadapi permasalahan yang kompleks, dalam bentuk pertanyaan, mendisain produk dan tugas.

Penelitian ini dilakukan untuk mencapai suatu tujuan. Dimana tujuan umum yang hendak dicapai dalam penelitian ini adalah mengetahui bagaimana pengaruh projek terhadap kemampuan kognitif siswa. Secara terperinci, tujuan penelitian ini adalah sebagai berikut:

1. Mengetahui peningkatan kemampuan kognitif siswa sebagai impak penerapan model pembelajaran kooperatif tipe numbered head together (NHT) dengan pendekatan projek.

2. Mengetahui profil peningkatan setiap aspek kemampuan kognitif pada materi optik melalui penerapan model pembelajaran kooperatif tipe numbered head together (NHT) dengan pendekatan projek.

Hasil penelitian ini diharapkan dapat memeberikan bukti tentang potensi model pembelajaran kooperatif tipe numbered head together (NHT) dengan pendekatan projek dalam meningkatkan kemampuan kognitif siswa, yang nantinya dapat memperkaya hasil-hasil penelitian sejenis yang telah dilakukan sebelumnya dan dapat digunakan oleh berbagai pihak yang berkepentingan, seperti: guru-guru fisika, dosen dan mahasiswa di LPTK, para peneliti, dan para tenaga kependidikan lainnya yang terkait dengan pembelajaran IPA Fisika.

\section{METODE}

Pada bagian metode ditulis dengan panjang $15 \%-20 \%$ dari seluruh isi artikel. Metode berisi rancangan atau desain penelitian, populasi dan sampel (sasaran penelitian), teknik pengumpulan data dan pengembangan instrumen, dan teknik analisis data.

Penelitian yang menggunakan alat dan bahan, perlu dituliskan spesifikasi alat dan bahannya. Spesifikasi alat menggambarkan kecanggihan alat yang digunakan sedangkan spesifikasi bahan menggambarkan macam bahan yang digunakan.

\section{HASIL DAN PEMBAHASAN}

Peningkatan kemampuan kognitif dilihat menggunakan gain ternormalisasi yang diungkapkan oleh Hake R.R (Vincened, 2005:1172). Gain didapat dari nilai pretes dengan postes tertera pada lampiran D.2. Perolehan gain setelah dilaksanakan penerapan model NHT dengan pendekatan projek sebesar 0,41 nilai gain tersebut terdapat pada kategori sedang yaitu berkisar antara $0,3<g<0,7$. Sehingga dapat disimpulkan bahwa penerapan model NHT dengan pendekatan projek dapat meningkatkan kemampuan kognitif siswa.

Peningkatan kemampuan kognitif siswa dilihat menggunakan gain yang dikemukakan oleh Hake R.R (Vincened, 2005:1172) pada setiap kemampuan. Peningkatan setiap kemampuan kognitif ditunjukkan oleh gambar diagram di bawah ini.

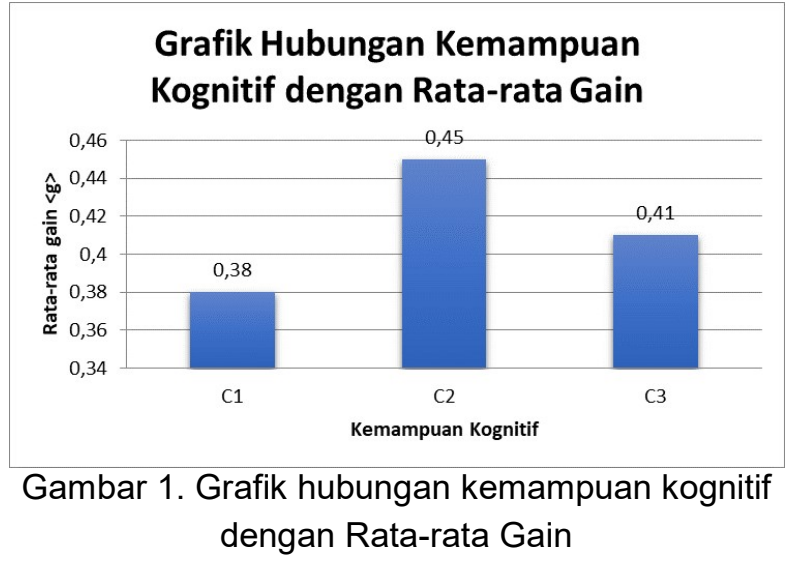


Kemampuan kognitif belajar siswa dapat meningkat ketika diterapkan model pembelajaran NHT dengan pendekatan projek. Peningkatan prestasi belajar siswa dapat dikategorikan sedang menurut Hake R.R (Vincened, 2005:1172) terlihat dari gambar 1. Peningkatan prestasi belajar terdapat pada kategori sedang ini disebabkan karena beberapa faktor diantaranya: (1) siswa kurang dilatihkan pada permasalahan yang variatif, sehingga ketika siswa dihadapkan pada permasalahan yang berbeda mereka kurang dapat menyelesaikannya; (2) pendekatan pembelajaran yang dilakukan merupakan pendekatan yang baru, sehingga siswa harus beradaptasi terhadap pembelajaran. Ini terbukti setiap siswa mengikuti kegiatan pembelajaran aktivitas siswa cenderung rendah disetiap pertemuan. Akan tetapi aktivitas siswa tersebut memeperlihatkan peningkatan untuk setiap pertemuan; (3) Tidak adanya konfirmasi kepada siswa untuk pertemuan kedua. Ini dikarenakan konfirmasi dari guru yang bersangkutan untuk memasuki jadwal pembelajaran disampaikan kepada penulis pada sore hari, jadi tidak ada kesempatan untuk penulis melakukan konfirmasi kepada siswa. Jadwal yang diberikan adalah pada hari rabu jam kesatu dan kedua. Mata pelajaran yang digunakan adalah mata pelajaran bahasa Indonesia. Hal ini berakibat pada psikologi siswa. Siswa belum siap mengikuti pembelajaran fisika. Siswa hanya mempersiapkan pembelajaran bahasa Indonesia seperti jadwal biasanya; (4) adanya ketidaksesuaian waktu yang direncanakan dengan pelaksanaan. Perangkat pembelajaran yang disiapkan oleh penulis untuk waktu 2X45 menit sedangkan waktu yang diberikan sekolah 2 X40 menit. Hal ini berakibat pada proses pembelajaran yang terburu-buru karena kegiatan pembelajaran cukup banyak sedangkan waktu yang disediakan sedikit; (5) Lemahnya pengetahuan dasar siswa mengenai materi yang dijadikan proyek. Hal ini dapat terlihat dari LKS yang didiskusikan, kebanyakan siswa masih menjawab salah; (6) Meskipun secara kuantitatif seluruh tahapan pembelajaran dapat dilaksanakan dengan oleh guru, tetapi secara kualitas pelaksanaan setiap tahapan pembelajaran masih belum dapat dikategorikan baik, masih banyak kegiatan yang tidak berjalan lancer. Penyebabnya tentu terkait dengan kemampuan guru dalam memfasilitasi kegiatan-kegiatan pembelajaran belum optimal.

Berdasarkan gambar diagram 1 diatas masih terdapat peningkatan aspek kemampuan kognitif tertentu yang masih rendah, sehingga mengakibatkan besar gain terdapat pada kategori sedang.

a. Kemampuan Mengingat (C1)

Berdasarkan gambar diagram diatas kemampuan mengingat mempunyai peningkatan paling rendah dibanding aspek kemampuan kognitif yang lain. Ini diakibatkan kebanyakan siswa yang menjawab soal yang mengukur aspek kemampuan mengingat masih salah. Soal yang mengukur kemampuan kognitif mengingat adalah nomor 1 dengan indikator ketercapaian menyebutkan bagian-bagian teropong. Soal nomor satu membahas tentang bagian-bagian lensa pada teropong. Siswa diminta untuk menunjukan lensa okuler dan lensa objektif pada teropong berdasarkan gambar. Kurangnya kemampuan siswa pada soal ini dikarenakan:

1) Dilihat dari soal, kurangnya gambar mata pada soal, karena yang siswa ketahui adalah lensa okuler adalah lensa yang dekat dengan mata sedangkan lensa objektif adalah lensa yang dekat dengan objek.

2) Dilihat dari keterlaksanaan pembelajarannya, pada pertemuan pertama keterlaksanaan siswa hanya terlaksana $69 \%$. Hal ini terjadi karena proses pembelajaran masih kaku, pada LKS tidak terdapat soal untuk menyebutkan bagian-bagian teropong, dan indikator ini hanya dilatihkan pada penguatan dan pembahasan.

b. Kemampuan Menerapkan (C3)

Berdasarkan gambar diagram diatas kemampuan menerapkan mempunyai peningkatan rendah setelah kemampuan mengingat. Ini diakibatkan kebanyakan siswa yang menjawab soal yang mengukur aspek kemampuan menerapkan masih salah. Soal yang mengukur kemampuan kognitif mengingat adalah nomor 13 
dengan indikator ketercapaiannya yaitu menghitung perbesaran yang dialami oleh sebuah teropong bintang dan nomor 14 dengan indikator ketercapaiannya yaitu menghitung panjang sebuah teropong bintang. Kurangnya kemampuan siswa pada soal ini dikarenakan:

1) Dilihat dari keterlaksanaan pembelajarannya, kemampuan menjawab soal nomor 13 dan 14 dilatihkan pada pertemuan kedua. Keterlaksanaan siswa pada pertemuan kedua hanya terlaksana 66,7. Hal ini terjadi karena siswa kurang dilatihkan menyelesaikan masalah menggunakan variasi soal, siswa hanya menyimak penjelasan guru pada soal yang divariasikan.

2) Dilihat dari soal yang diberikan siswa diminta untuk menghitung panjang teropong dari perbesaran dan jarak fokus objektif yang diketahui. Hal ini menjadi salah satu kesulitan bagi siswa, karena siswa terbiasa dengan menghitung langsung dari rumus yang ada belum terbiasa diberikan soal hitungan yang lebih vareatif.

\section{KESIMPULAN DAN SARAN}

Berdasarkan data hasil penelitian, pengolahan, dan analisis, terkait penerapan model kooperatif tipe numbered head together (NHT) dengan pendekatan projek dan impaknya terhadap peningkatan kemampuan kognitif siswa SMA terkait materi ajar teropong pada alat-alat optik, dapat ditarik kesimpulan sebagai berikut:

1. Penerapan model numbered head together (NHT) dengan pendekatan projek dalam pembelajaran teropong secara umum dapat meningkatkan kemampuan kognitif siswa. Hal ini ditunjukan oleh pencapaian rata-rata skor gain yang dinormalisasi $\langle\mathrm{g}\rangle$. Peningkatan kemampuan kognitif setelah diterapkannya model numbered head together (NHT) dengan pendekatan projek adalah sebesar 0,41. Dapat dikategorikan pada kategori sedang.

2. Profil peningkatan setiap aspek kemampuan kognitif siswa sebagai impak dari penerapan model numbered head together (NHT) dengan pendekatan projek adalah: jenjang kemampuan hapalan (C1), kemampuan memahami (C2), dan kemampuan menerapkan (C3) masing-masing meningkat dengan kategori sedang.

Dari penelitian yang telah dilakukan, penyusun mengajukan beberapa saran diantaranya.

1. model numbered head together (NHT) dengan pendekatan projek dapat digunakan dalam pembelajaran Fisika untuk meningkatkan kemampuan kognitif siswa.

2. Memberikan pertanyaan arahan yang dapat melatihkan siswa pada kinerja-kinerja kognitif yang dikemukakan Bloom.

3. Agar penerapan model pembalajaran numbered head together (NHT) dengan pendekatan projek dapat terlaksana dengan optimal, maka guru sebagai fasilitator seluruh kegiatan yang dilaksanakan dikelas, harus memiliki berbagai keterampilan dasar mengajar yang baik, seperti keterampilan berkomunikasi, keterampilan memotivasi, keterampilan bertanya, keterampilan berdiskusi, keterampilan dalam membuat alat, dan tentu keterampilan dalam mengelola kelas. Dengan demikian, penerapan model pembelajaran numbered head together (NHT) dengan pendekatan projek dapat lebih meningkatkan kemampuan kognitif siswa dibanding yang dicapai dalam penelitian ini.

4. Agar pelaksanaan pembelajaran model numbered head together (NHT) dengan pendekatan projek sesuai dengan waktu yang ditentukan sekolah, maka hendaknya guru melakukan semacam simulasi mengajar degan rencana dan scenario pembelajaran yang telah disusun. Dengan jalan demikian, maka dapat dilakukan pengalokasian waktu secara lebih cermat. 


\section{DAFTAR PUSTAKA}

Alma, Buchari. 2009. Guru Profesional Menguasai dan Terampil Mengajar. Bandung: Penerbit Alfabeta

Altun, Sema, dkk. (2009). "The Affect of Project based learning on Science Undergraduates' Learning of Electricity, Attitude toward Physics abd Sciebtific Proses Skill". International online journal of Educational Science,1(1), 81-105.

Ardiansyah, Asrori. (2011). Tujuan Pembelajaran Kooperatif (Cooperative Learning). [Online]. Tersedia:

http://www.majalahpendidikan.com/2011/0 4/tujuan-pembelajaran-kooperatif.html [9 Agustus 2012].

Arikunto, Suharsimi. (2006). Prosedur Penelitian: Suatu Pendekatan Praktek. Jakarta: Rineka Cipta.

Arikunto, Suharsimi. (2008). Dasar-dasar Evaluasi Pendidikan. Jakarta: Bumi Aksara.

Clark A. (2006). Changing classroom practice to include the Project approach. Early Childhood Research \& Practice, 8(2). Tersedia: http://ecrp.uiuc.edu/v8n2/clark.html. Retrieved 8 Oct 2007.

Depdiknas. (2006). Standar Isi untuk Satuan Pendidikan Dasar dan Menengah. Jakarta: Depdiknas.

Edward, Gloria J. (2002). "Make Your Own ProjectBased Lesson Plan". Educator and Curriculum Development Specialist Unlimited Learning. 12-13.

Hake, R.R. (2007). Should We Measure Change? Yes!. [Online]. Tersedia: http://www. physics.indiana.edu/ hake

Hake, Richard R. (1999). Analyzing Change/ Gain Scores. Amerika: Indiana University.

Hakim, Mohammad Iksanul. (2009). Penerapan Model Numbered Head Together (NHT) pada Pembelajaran Fisika untuk Meningkatkan Aktivitas Dan Prestasi Belajar Siswa. Bandung: Skripsi Program S1 (tidak diterbitkan).

Helm, J. H., \& Beneke, S. (2003). The power of projects: Meeting contemporary challenges in early childhood classrooms-strategies and solutions. New York: Teachers College Press.
Karli, H. dan Yuliariatiningsih, M.S. (2003). ModelModel Pembelajaran. Bandung : Bina Media Informasi.

Katz, L. (1994). The project approach. ERIC digest. Champaign, IL: ERIC Clearinghouse on Elementary and Early Childhood Education.

Koswara, T. (2010). Penerapan Model Pembelajaran Kontruktivisme dalam Pembelajaran Fisika untuk Meningkatkan Prestasi Belajar Siswa SMP. Skripsi FPMIPA UPI; tidak diterbitkan.

Krajcik, JS, Czerniak, CM \& Berger, CF. (1999). Teaching science: a project-based approach. New York: McGraw-Hill College.

Lie, Anita. (2002). Cooperatif Learning Mempraktikan Cooperatif Learning Di Ruang-Ruang Kelas. Jakarta : PT. Gramedia

Mitchell, Sacha, dkk. (2009). "The Negotiated Project Approach: Project based learning Without leaving the Standars Behind". Early Childhood Aduc J 36:339-346.

Munaf, Syambasri. (2001). Evaluasi Pendidikan Fisika. Bandung: Jurisan Pendidikan Fisikan UPI.

Nasution, S. (1996). Pengertian Prestasi Belajar. [Online]. Tersedia: http://www.pengertiandefinisi.com/2012/01/pe ngertian-prestasi-belajar.html[15 Juli 2012)

Noname. (2011). Fisika itu Mudah/Pendekatan. [online]. Tersedia http://id.wikibooks.org/wiki/Fisika itu mudah/ Pendekatan [29 November 2011].

Noname. (2011). Ilmu Alam. Wikipedia [online]. Tersedia:

http://id.wikipedia.org/wiki/llmu_alam

Poedjiadi, A. (2005). Sains Teknologi Masyarakat; Model Pembelajaran Kontekstual Bermuatan Nilai. Bandung : Remaja Rosdakarya.

Sanjaya. (2009). Pengertian Pendekatan, Strategi, Metode, Teknik, dan Model Pembelajaran. Edukation For A Better Live [online].Tersedia:http://akhmadsudrajat.wordp ress.com/2008/09/12/pendekatan-strategimetode-teknik-dan-model-pembelajaran/ [12 November 2011].

Selçuk, Gamze Sezgin. Et al. (2008). The Effects of Problem Solving Instruction on Physics Achievement, Problem Solving Performance and Strategy Use. Latin American Journal 
Physics Education volume 2 No. 3 September 2008.

Siroj, R. A, (2004). Pemerolehan Pengetahuan Menurut Pandangan Konstruktivistik. [online].

Solamo, Rowena. (2008). Project Based Learning Approach in Teaching Introductory Course In Programming. Philipina: University of the Philippines.

Sriayu. (2009). Numbered Head Together. [Online] Tersedia:

http://pelawiselatan.blogspot.com/2009/03/num ber-head-together.html [9 Agustus 2012].

Sudjana, Nana. (2007). Penilaian Hasil Proses Belajar. Bandung: Rosdakarya.

Sumarno, alim. (2011). Strategi Pembelajaran. [Online]. Tersedia http://elearning.unesa.ac.id/myblog/alimsumarno/strategi-pembelajaran[29 November 2011].

Suparno, P. (2001). Filsafat Konstruktivisme dalam Pendidikan. Yogyakarta : Kanisius.

Tarlington, D. (2003). Bloom's Revised Taxonomy. Presentation for Pupil Free Day, July 14, 2003. [Online]. Tersedia:

The North Carolina Graduation Project Implementation Guide. (2007). Project Rubrics and Description. North Carolina

Trianto. (2007). Model-Model Pembelajaran Inovatif Berorientasi Konstruktivistik. Cetakan pertama, Jakarta : Prestasi Pustaka Publisher.

Universitas Pendidikan Indonesia. (2011). Pedoman Penulisan Karya IImiah. Bandung: Universitas pendidikan Indonesia.

Winkel, W. S. (2009). Psikologi Pengajaran. Yogyakarta: 